\title{
DISEASE- AND PEST-RESISTANT LUCERNE CULTIVARS FOR NEW ZEALAND
}

\author{
M. W. DUNBIER, R. C. CLOSE*, AND T. J. ELLIS \\ Crop Research Division, DSIR, Christchurch \\ * Microbiology Department, Lincoln College, Canterbury
}

Summary

The discovery of bacterial wilt in New Zealand in 1970 meant that the susceptible cultivars of lucerne (Medicago sativa), 'Wairau', 'Hunter River', 'Chanticleer' and 'College Glutinosa' commonly grown in New Zealand would eventually have to be replaced with disease- and pest-resistant cultivars. Imported resistant cultivars have been extensively evaluated in Canterbury and 'Saranac' (resistant to bacterial wilt) and 'Washoe' (resistant to bacterial wilt and stem nematode) have been placed on the Acceptable Herbage Cultivar List. Further imported cultivars are being evaluated, and breeding is aimed at producing lucerne cultivars specifically for New Zealand conditions.

\section{INTRODUCTION}

Lucerne (Medicago sativa) culture in New Zealand has changed dramatically in the past 10 years as the influence of diseases and pests on production has become apparent. The gradual intensification of farming systems has, in the main, been responsible but a major factor was the discovery of bacterial wilt disease, caused by Corynebacterium insidiosum, in mid-Canterbury in 1970 (Close 1972). This meant that the susceptible cultivars, 'Wairau', 'Hunter River', 'Chanticleer' and 'College Glutinosa' which had been satisfactory for a considerable period would eventually have to be replaced with disease-resistant cultivars. This is more necessary now that bacterial wilt has been found in most areas of the South Island and in many parts of the North Island.

The best method of controlling many diseases and pests involves developing new cultivars with resistance based on stable genetic sources. This method is not costly and avoids adverse effects of chemicals on the environment, but it is a long-term solution, usually taking many years to develop a satisfactory cultivar.

Fortunately, the most important pests and diseases of lucerne in New Zealand are also present in other countries where plant breeders have already produced resistant cultivars or at least resistant breeding lines. As long as the disease resistance and agronomic performance of imported cultivars are satisfactory in New Zealand they may be used directly, and as sources of resistance in local breeding programmes.

This paper outlines the evaluation, since 1971 , of some recently imported disease-resistant cultivars and the progresss made with the New Zealand breeding programme.

Performance of resistant cultivars in New Zealand

Following the discovery of bacterial wilt many cultivars were imported from Europe and North America, initially for evaluation in Canterbury. These cultivars were sown in trials from 1971 onwards and preliminary evaluation (Palmer et al 1975) has indicated they can be Proc. 29th N.Z. Weed and Pest Control Conf. 
grouped according to their area of origin, disease resistance and performance in New Zealand. Information on some of the most promising of these cultivars is summarised in Tables 1 and 2 and Figs. 1 and 2.

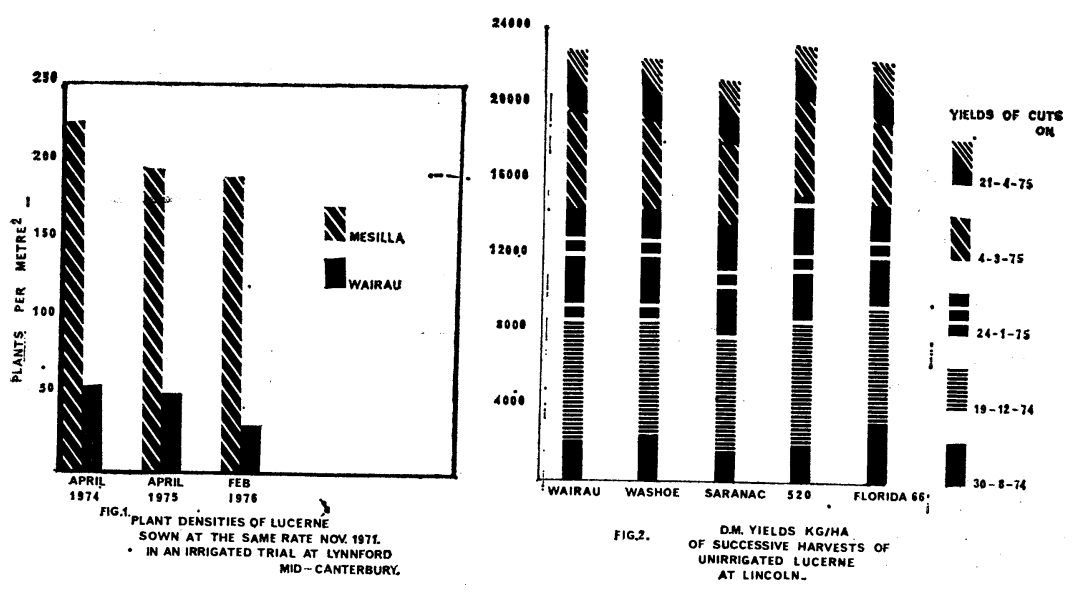

TABLE 1: YIELDS OF DRY MATTER RELATIVE TO TRIAL MEAN ( $=100)$, OF SEVERAL LUCERNE CULTIVARS SOWN IN 1971 ON LAND NOT RECENTLY IN LUCERNE

\begin{tabular}{|c|c|c|c|c|c|c|c|c|c|}
\hline \multirow[t]{2}{*}{ Cultivar } & \multicolumn{3}{|c|}{$\begin{array}{l}\text { Winchmore } \\
\text { (irrigated) }\end{array}$} & \multicolumn{2}{|c|}{$\begin{array}{l}\text { Winslow } \\
\text { (irrigated) }\end{array}$} & \multicolumn{4}{|c|}{ Lincoln } \\
\hline & $72 / 3$ & $73 / 4$ & $74 / 5^{*}$ & $73 / 4$ & $74 / 5$ & $72 / 3$ & $73 / 4$ & $74 / 5$ & $75 / 6$ \\
\hline 'Wairau' & 103 & 95 & 88 & 97 & 97 & 110 & 111 & 105 & 115 \\
\hline 'Saranac' & 113 & 111 & 108 & 104 & 99 & 101 & 101 & 97 & 103 \\
\hline 'Washoe' & 91 & 95 & 96 & 87 & 100 & 88 & 94 & 104 & 113 \\
\hline$' 520^{\prime}$ & 106 & 108 & 114 & 101 & 117 & 11 & 107 & 107 & 116 \\
\hline 'Florida 66' & - & - & - & 96 & 85 & 94 & 111 & 103 & 92 \\
\hline 'Mesilla' & 102 & 99 & 99 & 88 & 95 & - & - & - & - \\
\hline 'Iroquois' & 100 & 106 & 102 & 122 & 116 & 85 & 87 & 91 & 105 \\
\hline LSD $1 \%$ & 6 & 7 & 13 & 14 & NS & 10 & 6 & 11 & 14 \\
\hline
\end{tabular}

* By the 1974/75 season bacterial wilt had reduced the number of 'Wairau' plants present

Some overseas cultivars have produced at least as well as the standard cultivar, 'Wairau', in trials in Canterbury where bacterial will was not present (Table 1). In the presence of bacterial wilt resistant cultivars such as 'Saranac', 'Washoe', 'Mesilla' and '520' produced well and maintained stands where susceptible cultivars such as 'Wairau' and 'Florida 66' died out. Fig 1 shows plant densities in 'Mesilla' and 'Wairau' in a bacterial wilt-infected area in mid-Canterbury in the 2nd, 3rd, and 4th cutting seasons after sowing. The stands were sown at the same rate, established well and 'were managed similarly. 'Mesilla' maintained an adequate stand but the 'Wairau' plant density decreased until it was uneconomic to continue cutting. 


\section{Lucerne}

TABLE 2: RESISTANCE OF LUCERNE CULTIVARS IN TRIALS IN CANTERBURY TO SOME PESTS AND DISEASES COMMON IN NEW ZEALAND

\begin{tabular}{|c|c|c|c|c|c|c|}
\hline Cultivar & Origin & $\begin{array}{c}\text { Bacterial } \\
\text { wilt }\end{array}$ & $\begin{array}{c}\text { Stem } \\
\text { nematode }\end{array}$ & $\begin{array}{c}\text { Verticillium } \\
\text { wilt }\end{array}$ & $\begin{array}{l}\text { Leaf } \\
\text { spot }\end{array}$ & $\begin{array}{l}\text { Downy } \\
\text { mildew }\end{array}$ \\
\hline Wairau't & $\mathrm{NZ}$ & $\mathbf{S}$ & $s$ & $M R$ & $s$ & MR \\
\hline 'Hunter River't & Aust. & S & S & - & $\mathbf{S}$ & $\mathbf{S}$ \\
\hline 'Chanticleer' $t$ ' & France & S & s & MR & MR & $\mathbf{R}$ \\
\hline 'College Glutinosa't & $\mathrm{NZ}$ & $S$ & S & - & - & - \\
\hline 'Saranac't & USA-N.E. ${ }^{*}$ & $\mathbf{R}$ & $\mathbf{s}$ & MR & $\mathbf{R}$ & $\mathbf{R}$ \\
\hline 'Washoe' & USA-S.W. & $\mathbf{R}$ & $\mathbf{R}$ & $\mathrm{R}$ & $\mathbf{S}$ & S \\
\hline 'Gladiator' & USA-N.C. & $\mathbf{R}$ & $\mathbf{R}$ & 一 & (R) & $R$ \\
\hline 'Mesilla' & USA-S.W. & $\mathbf{R}$ & - & - & S & $\mathbf{S}$ \\
\hline '520' & USA-N.C. & $\mathbf{R}$ & - & $\mathbf{R}$ & $\mathbf{R}$ & $\mathbf{R}$ \\
\hline 'Iroquois' & USA-N.E. & $\mathbf{R}$ & - & $\mathbf{R}$ & $\mathbf{R}$ & $\mathbf{R}$ \\
\hline 'Florida 66' & USA-S.E. & $M R$ & - & - & $\mathbf{R}$ & $\mathbf{R}$ \\
\hline 'Vertus' & Sweden & $\mathbf{S}$ & (R) & (R) & - & $\mathbf{R}$ \\
\hline 'Maris Kabul' & UK & MR & - & (R) & - & $\mathbf{R}$ \\
\hline
\end{tabular}

$\begin{array}{ll}\text { * regions in USA } & \text { Key: } \mathrm{R}=\text { Resistant } \\ \text { N.C. }=\text { North Central } & \mathrm{MR}=\text { Moderately resistant } \\ \text { N.E. }=\text { North East } & \mathrm{S}=\text { Susceptible } \\ \text { S.E. }=\text { South East } & -=\text { No information available } \\ \text { S.W. = South West } & \text { Values in brackets are overseas } \\ & \text { reports not yet confirmed in NZ }\end{array}$

$\dagger=$ On Acceptable Herbage Cultivar List

Fig 2, illustrating yields of the fourth season of an unirrigated stand at Lincoln, shows that the cultivars 'Washoe', '520' and 'Saranac' have a similar growth pattern to 'Wairau'. However, 'Florida 66' grows consimilar growth pattern to 'Wairau'. However, 'Florida former, probably more than compensates for the slightly lower summer production. In areas where winter temperatures are milder the cool season growth potential of cultivars like "Florida 66" should be even more evident.'

Table 2 lists the disease and pest resistance of cultivars on the Acceptable Herbage Cultivar List, and of others 'with useful resistance to Acces pests and diseases of significance in New Zealand. Overseas reports show that resistance is available to other pests and diseases present in New Zealand. The following cultviars or breeding lines are being evaluated at Crop Research Division: cv 'Arc' is resistant to anthracnose (Colletotrichum trifolii), cv 'Agate' resistant to phtyophthora root-rot (Phytophthora megasperma), line MSACW3 AN3 resistant to rust (Uromyces striatus), cv 'Ramsey' is resistant to spring blackstem (Phoma medicaginis), line 'Nevada Synthetic xx', and 'Moapa 69' are resistant to root-knot nematode (Meloidogyne spp), and two California breeding lines are resistant to the blue-green lucerne aphid (Acyrthosiphon kondoi).

\section{Discussion}

Evaluation of overseas cultivars has shown that those described as resistant to the important pests and diseases show good field resistance in New Zealand and that some of them also produce very well. A pattern has emerged from the results showing a relation between the area where the cultivars were bred and their likely success in New Zealand. Most of the North American lucerne cultivars performing best in Canterbury trials were bred in the severe winters and warm, humid summers of the North-Central and North Eastern regions of the U.S.A. New Zealand winters are much less severe and initially it was considered that cultivars from areas with a less severe 'winter would be more suitable. However, all the winter-active cultivars initially introduced were from the Great Plains or South-Western regions of the U.S.A., and these cultivars, bred in areas with dry climates and low humidities, suffer severely from foliar diseases in our more humid climate, and their performance is 
generally unsatisfactory. Further cultivars to be imported from the U.S.A. will probably be from the North-Central, North-Eastern, or South-Eastern regions. For the North Island, where temperature and humidity are generally higher, cultivars from the South-Eastern U.S.A. are likely to show most promise. The high resistance to leaf diseases of the cultivar bred in humid regions may give other benefits, for example, reduced phyto-oestrogen levels which may improve lambing percentages in ewes flushed and mated on lucerne.

While the best of the imported lucerne cultivars are satisfactory in New Zealand, none is ideal. There is a real need for continued breeding work in New Zealand to produce disease-resistant lucerne cultivars specifically for our conditions. The present state of lucerne cultivar development in New Zealand is similar to that in the U.S.A. about 40 years ago. However, because there are resistant cultivars to use as parents, and because screening techniques are now well established (Barnes et al 1974), rapid progress can be expected. In breeding lucerne, cultivars resistant to a single pest or disease have been produced first, and then resistance to other pests or diseases has been added so that finally all the - necessary forms of resistance are incorporated in the one cultivar. This programme has taken 30-40 years in the U.S.A., but by making use of the latest techniques the Crop Research Division breeding programme will produce cultivars resistant at least to bacterial wilt and stem nematode in 10 years. Bacterial wilt- and stem nematode-resistant selections have been made after screening in the glasshouse. The progeny of intercrosses among these plants are now being evaluated for disease-resistance in the glasshouse, and for productivity in the field.

Future objectives are to incorporate resistance to a greater range of pests and diseases e.g. leaf diseases, verticillium wilt, phytophthora rootrot, root-knot nematode, sitona weevil (Sitona humeralis), and blue-green lucerne aphid in cultivars that give high yields of quality forage. As the major problems are tackled this 'will allow other characters such as cool season production, digestibility, and tolerance to repeated defoliation to be considered. The prospects and challenges are exciting and the results should be very beneficial to lucerne growers in New Zealand and to industries dependent on the crop.

\section{REFERENCES}

Barnes, D.K., Frosheiser, F.I., Sorenson, E.L., Elgin, J.H., Nielson, M.W., Lehman, W.F., Leath, K.T., Ratcliffe, R.H. and Buker, R.J., 1974. Standard tests to characterise pest resistance in alfalfa varieties. Agricultural Research Service, U.S.D.A., A.R.S. - NC $1923 \mathrm{pp}$

Close, R.C., 1972. Diseases of lucerne in New Zealand. Proc. 25th N.Z. Weed and Pest Control Conf.,: 106-109.

Palmer, T.P., Dunbier, M.W., Janson, C.G. and Woodhead, M., 1975. Lucerme cultivars in New Zealand. Proc. Agronomy Society of New Zealaind. 5: 33-36. 